\title{
Analisa Rasio Keuangan dan Ukuran Perusahaan terhadap Harga Saham Perusahaan Infrastruktur dan Utilitas dan Transportasi di Indonesia.
}

\section{Gito Hutabarat}

Universitas Prima Indonesia

gito.matty@gmail.com

\section{Ledifraoneva}

Universitas Prima Indonesia

ledifraoneva@gmail.com

\section{Yuliade. I}

Universitas Prima Indonesia

yuliade_irawan@yahoo.co.id

\section{Meisin. N}

Universitas Prima Indonesia meisinnainggolan@gmail.com

\begin{abstract}
Abstrak Tujuan penelitian ini adalah untuk membuktikan dan menganalisis ada tidaknya pengaruh rasio keuangan dan ukuran perusahaan terhadap harga saham perusahaan sektor infrastruktur, utilitas dan transportasi yang terdaftar di Bursa Efek Indonesia. Penelitian ini menggunakan pendekatan kuantitatif.Populasi dalam penelitian ini adalah seluruh perusahaan infrastruktur dan transportasi yang terdaftar di Bursa Efek Indonesia periode 2014-2017. Teknik pengambilan sampel menggunakan teknik sampling purposive dengan jumlah sampel yang diperoleh sebanyak17 perusahaan. Model penelitian ini menggunakan analisis regresi linier berganda dengan metode Ordinary Least Square. Hasil empiris penelitian ini menunjukkan bahwa secara parsial variabel Net Profit Margin (NPM) dan ukuran perusahaan berpengaruh positif dan signifikan terhadap harga saham, sedangkan variabel Debt to Equity Ratio (DER) tidak berpengaruh. Sedangkan secara simultan variabel DER, NPM dan ukuran perusahaan berpengaruh signifikan terhadap harga saham. Nilai koefesien determinasi sebesar 0,461 menunjukan bahwa hanya sebesar $46 \%$ variabel harga saham yang dapat dijelaskan oleh variabel DER, NPM dan ukuran perusahaan sedangkan sisanya sebesar 54\% dijelaskan oleh variabel lainnya yang tidak diteliti dalam penelitian ini.
\end{abstract}

Kata Kunci Debt to Equity Ratio, Net Profit Margin,Ukuran Perusahaan, Harga Saham 


\section{PENDAHULUAN}

Sektor infrastruktur merupakan sektor yang paling menarik sepanjang tahun 2014-2017 karena adanya dukungan dan rencana pemerintah dalam pengembangan infrastruktur di Indonesia. Alokasi belanja infrastruktur dalam APBN meningkat karena pembangunan infrastruktur secara besar-besaran. Infrastruktur merupakan salah satu sektor andalan untuk memacu tingkat pertumbuhan ekonomi. Namun pembangunan infrastruktur terkendala dengan masalah dana yang besar. Karena anggaran pemerintah yang terbatas, untuk itu, pemerintah sangat memerlukan dukungan dari pihak swasta dalam hal ini investor untuk dapat menginvestasikan dananya pada pembangunan infrastruktur di Indonesia. Namun pertumbuhan harga saham sektor infrastruktur berjalan secara stagnan dan beberapa emiten mengalami pelemahan.

Saham salah satu instrument pasar keuangan yang popular. Menerbitkan saham merupakan salah satu pilihan perusahaan ketika memutuskan untuk pendanaan perusahaan. Pada sisi yang lain, saham sebagai salah satu alat untuk mencari tambahan dana menyebabkan kajian dan analisis tentang saham begitu berkembang baik secara fundamental dan teknikal. Berbagai literatur mencoba memberikan rekomendasi yang berbeda-beda namun tujuannya sama yaitu ingin memberikan profit yang tinggi bagi pemakainya, serta memiliki dampak keputusan yang bersifat berkelanjutan.

Ada beberapa faktor yang dapat mempengaruhi harga saham antara lain kondisi mikro dan makro ekonomi, kebijakan perusahaan dalam memutuskan ekspansi (perluasan) atau memperbesar perusahaan, pergantian direksi secara tiba-tiba, kinerja keuangan seperti kinerja profitabilitas perusahaan yang terus mengalami penurunan (Fahmi : 2012:86)

Tujuan dari penelitian ini adalah untuk menganalisis :

1. Pengaruh Debt to Equity Ratio (DER) terhadap harga saham perusahaan Infrastruktur, utilitas dan transportasi yang terdaftar di Bursa Efek Indonesia .

2. Pengaruh Net Profit Margin (NPM) terhadap harga saham perusahaan Infrastruktur, utilitas dan transportasi yang terdaftar di Bursa Efek Indonesia.

3. Pengaruh Ukuran Perusahaan terhadap harga saham perusahaan Infrastruktur, utilitas dan transportasi yang terdaftar di Bursa Efek Indonesia.

4. PengaruhDebt to Equity Ratio (DER) , Net Profit Margin (NPM) dan Ukuran Perusahaan terhadap harga saham perusahaan Infrastruktur, utilitas dan transportasi yang terdaftar di Bursa Efek Indonesia.

\section{LANDASAN TEORI}

\subsection{Teori Saham}

Menurut Ramdhani (2017:178) harga saham di pasar modal sangat ditentukan oleh kekuatan permintaan dan penawaran, semakin banyak investor yang membeli saham,semakin tinggi harga saham tersebut. Harga saham di dalam perdagangan dan investasi adalah harga saham yang mengacu pada harga saham terkini dalam perdagangan saham.Sedangkan Menurut Darmadji dan Fakhruddin (2012: 19) harga saham adalah surat berharga yang bersifat penyertaan, artinya seseorang membeli saham suatu perusahaan, maka ia telah melakukan penyertaan modal atas perusahaan tersebut.

Berdasarkan beberapa pendapat diatas maka dapat disimpulkan bahwa saham merupakan bukti kepemilikan investor terhadap perusahaan dengan mengikut sertakan 
modalnya keperusahaan. Harga saham Menurut Kodrat dan Indonanjaya (2010:13), adalah harga penutupan atau close price.

\subsection{Teori Debt to Equity Ratio(DER)}

Menurut Hery (2015 : 198), Debt to Equity Ratio (DER) adalah perbandingan antara jumlah dana yang disediakan oleh kreditor dengan jumlah dana yang berasal dari pemilik perusahaan. DER mengukur besarnya proporsi utang terhadap modal. Dengan kata lain, berfungsi untuk mengetahui berapa bagian dari setiap rupiah modal yang dijadikan sebagai jaminan utang.

Banyak faktor yang mempengaruhi debt to equity ratio. Menurut Sartono (2010:248-249) faktor-faktor yang mempengaruhi debt to equity ratio (DER) antara lain sebagai berikut:

1. Tingkat penjualan, perusahaan dengan penjualan yang relatif stabil berarti memiliki aliran kas yang relatif stabil pula, maka dapat menggunakan utang lebih besar dari pada perusahaan dengan penjualan yanng tidak stabil.

2. Struktur aktiva, perusahaan yang memiliki aktiva tetap dalam jumlah besar dapat menggunakan utang dalam jumlah besar. Hal ini disebabkan karena dari skala perusahaan besar akan lebih mudah mendapatkan akses ke sumber dana dibandingkan dengan perusahaan kecil.

3. Tingkat pertumbuhan perusahaan, semakin cepat pertumbuhan perusahaan maka semakin besar kebutuhan dana untuk pembiayaan ekspansi.

4. Profitabilitas periode sebelumnya merupakan faktor penting dalam menentukan srtuktur modal. Dengan laba ditahan yang besar, perusahaan akan lebih senang menggunakan laba ditahan sebelum menggunakan utang atau menerbitkan saham baru.

5. Variabilitas laba dan perlindungan pajak, perusahaan dengan variabilitas laba yang kecil akan memiliki kemampuan yang lebih besar untuk menanggung beban tetap yang berasal dari utang.

6. Skala perusahaan, perusahaan besar yang sudah mapan akan lebih mudah memperoleh laba dipasar modal dibandingkan dengan perusahaan kecil

7. Kondisi intern perusahaan dan ekonomi makro, perusahaan perlu melihat saat yang tepat untuk menjual saham dan obligasi.

IndikatorDebt to Equity Ratio (DER) adalah sebagai berikut : (Umam dan Susanto,2017 : 55) Total Hutang

\section{Debt to Equity Ratio $=$ Total Ekuitas}

Total hutang diperoleh dari penjumlahan hutang jangka pendek dan hutang jangkapanjang, sedangkan Total Ekuitas diperoleh dari penjumlahan ekuitas yang dapat didistribusikan kepada pemilik entitas induk dengan kepentingan non pengendali.

\subsection{Teori Profitability (NPM)}

Menurut Hery (2015 : 226), profitabilitas adalah alat untuk mengukur tingkat efektivitas kinerja manajemen . kineja yang baik akan ditunjukkan lewat keberhasilan manajemen dalam menghasilkan laba yang maksimal bagi perusahaan. 
Indikator profitabilitas dalam penelitian ini menggunakan Net Profit Margin(NPM). Menurut Kasmir (2012:200), NPM sebagai ukuran keuntungan dengan membandingkan antara laba setelah pajak dibandingkan dengan penjualan.

Dalam Sudana (2015 : 26), NPM dapat diformulasikan sebagai berikut :

$$
\mathrm{NPM}=\frac{\text { Laba Setelah Pajak }}{\text { Penjualan }}
$$

\subsection{Teori Ukuran Perusahaan}

Data kontrol biasanya dipergunakan untuk tujuan adakah data dari objek yang diteliti memiliki perbedaan karakteristik (memiliki karakteristik spesifik) tertentu. Variabel kontrol yang sering dipakai adalah ukuran perusahaan. Dalam hal ini biasanya ukuran perusahaan muncul sebagai variabel penjelas.

Proksi ukuran perusahaan biasanya adalah total aset perusahaan. Karena aset biasanya sangat besar nilainya untuk menghindari bias skala maka besaran aset perlu dikompres. Secara umum proksi ukuran perusahaan dipakai Logaritme Natural Asset .

Menurut Riyanto (2009:302), besarnya optimum perusahaan adalah berbeda-beda bagi setiap perusahaan, dan didalam suatu perusahaan efesiensi maksimum dari tenaga kerja, modal dan manajemen adalah berubah-ubah pada tingkat pertumbuhan yang berbeda-beda. Besarnya optimum perusahaan adalah selalu berubah-ubah, dan hal ini dipengaruhi oleh banyak faktor, antara lain :

1. Besarnya dan watak dari persaingan

2. Berubahnya kesukaan konsumen

3. Kemajuan teknologi atau konjungtur

\begin{tabular}{|c|c|c|c|c|}
\hline No & $\begin{array}{l}\text { Nama dan } \\
\text { Tahun } \\
\text { penelitian }\end{array}$ & Judul & Variabel & Hasil penelitian \\
\hline 1 & $\begin{array}{l}\text { Frendy } \\
\text { Sondakh, } \\
\text { Prengkuan } \\
\text { Tommy, } \\
\text { Marjam } \\
\text { Mangantar } \\
(2015)\end{array}$ & $\begin{array}{l}\text { Pengaruh CR, } \\
\text { DER, ROA dan } \\
\text { ROE terhadap } \\
\text { harga saham pada } \\
\text { perusahaan } \\
\text { Indeks LQ } 45 \text { di } \\
\text { Bursa Efek } \\
\text { Indonesia periode } \\
\text { 2010-2014 }\end{array}$ & $\begin{array}{l}\text { Variabel } \\
\text { Independen: } \\
\text { CR, DER, } \\
\text { ROA dan } \\
\text { ROE } \\
\text { Dependen: } \\
\text { Harga Saham }\end{array}$ & $\begin{array}{l}\text { CR berpengaruh positif } \\
\text { terhadap harga saham } \\
\text { DER berpengaruh positif } \\
\text { terhadap harga saham, } \\
\text { ROA berpengaruh positif } \\
\text { terhadap harga saham } \\
\text { ROE berpengaruh positif } \\
\text { terhadap harga saham }\end{array}$ \\
\hline 2 & $\begin{array}{l}\text { Rosdiana } \\
\text { Widianti } \\
\text { Watung, Ventje } \\
\text { Ilat (2016) }\end{array}$ & $\begin{array}{lr}\text { Pengaruh } & R O A, \\
N P M \text {, dan } & E P S \\
\text { terhadap } & \text { harga } \\
\text { saham } & \text { pada } \\
\text { perusahaaan } & \\
\text { Perbankan } & \text { di } \\
\text { bursa } & \text { efek }\end{array}$ & $\begin{array}{l}\text { Variabel } \\
\text { Independen: } \\
R O A, \quad N P M \text {, } \\
\text { dan EPS } \\
\text { Variabel } \\
\text { Dependen: } \\
\text { Harga Saham }\end{array}$ & $\begin{array}{l}\text { ROA berpengaruh positif } \\
\text { terhadap harga saham } \\
\text { NPM berpengaruh positif } \\
\text { terhadap harga saham }\end{array}$ \\
\hline
\end{tabular}

\section{Penelitian Terdahulu}




\begin{tabular}{|c|c|c|c|c|}
\hline & & $\begin{array}{l}\text { indonesia periode } \\
2011-2015\end{array}$ & & \\
\hline & $\begin{array}{l}\text { Ruttanti Indah } \\
\text { Mentari(2013) }\end{array}$ & $\begin{array}{lr}\text { Dampak } & \text { ROE, } \\
\text { NPM,CSR, dan } \\
\text { Ukuran } \\
\text { Perusahaan } \\
\text { terhadap } \\
\text { saham harga } \\
\text { perusahaan yang } \\
\text { tercantum dalam } \\
\text { LQ45 di } \\
\text { Periode } \\
2012\end{array}$ & $\begin{array}{l}\text { variabel } \\
\text { independen: } \\
\text { ROE,NPM, } \\
\text { CSR, Ukuran } \\
\text { Perusahaan. } \\
\text { Dependen: } \\
\text { Harga Saham }\end{array}$ & $\begin{array}{l}\text { ROE berpengaruh signifikan } \\
\text { secara persial terhadap harga } \\
\text { saham } \\
\text { NPM berpengaruh signifikan } \\
\text { terhadap harga saham } \\
\text { CSR berpengaruh signifikan } \\
\text { terhadap harga saham } \\
\text { Ukuran Perusahaan } \\
\text { berpengaruh signifikan } \\
\text { terhadap harga saham }\end{array}$ \\
\hline
\end{tabular}

\subsection{Teori Pengaruh Debt To Equity Ratio Terhadap Harga Saham}

Menurut Kodrat \& Indonanjaya (2010:283), hubungan antara harga saham seharusnya (nilai intrinsik) dengan Debt to Equity Ratio (DER) adalah positif, yaitu semakin besar rasio antara hutang dengan modal, semakin besar harga dari saham.

\subsection{Teori Pengaruh Net Profit Margin Terhadap Harga Saham}

MenurutHery (2015:199), Semakin tinggi margin laba bersih berart isemakin tinggi pula laba bersih yang dihasilkan dari penjualan bersih. Maka semakin tinggi penjualan bersih akan menaikkan harga saham pula.

\subsection{Teori Pengaruh Firm Size Terhadap Harga Saham}

Menurut Riyanto (2013 : 304), makin besarnya perusahaan, makin kuat pula kedudukanya dalam pasar uang atau pasar modal sehingga pasar bagi sekuritasnya adalah lebih baik, dan kemungkinan untuk mendapatkan modal dengan biaya yang lebih rendah adalah lebih besar.

\subsection{Kerangka Konseptual}



Gambar.1. Kerangka Konseptual 


\section{METODE PENELITIAN}

Dalam penelitian ini menggunakan pendekatan penelitian kuantitatif merupakan penelitian untuk mengetahui pengaruh atau hubungan antara variable bebas dengan variable terikatnya (Sugiyono, 2012:13). Populasi yang akan digunakan dalam penelitian ini adalah semua perusahaan pada sektor Infrastruktur, utilitas dan transportasi yang terdaftar di Bursa Efek Indonesia periode 2014-2017yang berjumlah 17 perusahaan. Populasi adalah keseluruhan yang terdiri atas objek atau subjek yang mempunyai karakteristik tertentu yang ditetapkan dan ditarik kesimpulannya (Sujarweni, 2014:65).Sedangkan sampel adalah bagian dari jumlah yang dimiliki populasi yang digunakan untuk penelitian (Sujarweni, 2014:65). Teknik pengambilan sampel menggunakan teknik purposive sampling yaitu teknik pengambilan sampel yang menggunakan kriteria (Sanusi, 2014:32).

Teknik pengumpulan data dalam penelitian ini menggunakan studi dokumentasi yaitu mengumpulkan data, dari Bursa Efek Indonesia periode tahun 2014 sampai dengan tahun 2017 yang diperoleh peneliti secara tidak langsung melalui media perantara internet diambil langsung dari situs Bursa Efek Indonesia (www.idx.co.id).

Penelitian ini menggunakan model regresi linier berganda. Model analisis ini digunakan dengan suatu alasan untuk melihat ada tidaknya pengaruh beberapa variabel bebas terhadap variabel tidak bebas, baik secara simultan atau bersama-sama maupun secara parsial atau masing-masing (Sanusi, 2014:134). Berdasarkan itu semua, maka spesifikasi model yang digunakan dalam penelitian ini adalah :

$$
\mathbf{Y}=\mathbf{a}+\mathbf{b}_{1} \mathbf{X}_{1}+\mathbf{b}_{2} \mathbf{X}_{2}+\mathbf{b}_{3} \mathbf{X}_{3}+\mathbf{e}
$$

Dimana :

$$
\begin{array}{ll}
\mathrm{Y} & =\text { Harga Saham } \\
\mathrm{X}_{1} & =\text { Debt to Equity Ratio } \\
\mathrm{X}_{2} & =\text { Net Profit Margin } \\
\mathrm{X}_{3} & =\text { Ukuran perusahaan } \\
\mathrm{b}_{0}, \mathrm{~b}_{1}, \mathrm{~b}_{2}, \mathrm{~b}_{3} & =\text { koefesien regresi } \\
\mathrm{a} & =\text { konstanta } \\
\mathrm{e} & =\text { standart error }
\end{array}
$$

Tahapan pengujian yang dilakukan dalam penelitian ini meliputi :

1. Statistik Deskriptif

2. Uji Asumsi Klasik

- Uji Normalitas (bertujuan untuk menguji apakah dalam model regresi, variabel pengganggu atau residual memiliki distribusi normal). Pengujian secara uji normalitas melalui uji statistik non-parametik kormologrov-smirnov (Ghozali, 2013:156)

- Uji Multikolinieritas (bertujuan untuk menguji apakah model regresi ditemukan adanya kolerasi antar variabel bebas). Pengujian secara uji multikolonieritas dengan melihat nilai tolerance dan VIF (Ghozali, 2013:103)

- Uji Autokorelasi (bertujuan menguji apakah dalam model regresi linear ada korelasi antara kesalahan pengganggu pada periode $t$ dengan kesalahan pengganggu pada perode t-1). Pengujian dengan uji autokorelasi dengan menggunakan uji Durbin-Watson (Ghozali, 2013:107) 
- Uji Heteroskedastisitas (bertujuan untuk menguji apakah dalam model regresi terjadi ketidaksamaan variance dari residual satu pengamatan ke pengamatan yang lain). Pengujian dengan uji heteroskedastisitas dengan menggunakan uji Spearman's Rho (Priyatno, 2017:108)

3. Model Analisis Data penelitian

- Uji Koefisien Determinasi $\left(\mathrm{R}^{2}\right)$

Mengukur seberapa jauh kemampuan model dalam menerangkan variasi variabel dependen (Ghozali, 2013:95)

- Secara Parsial

Untuk mengetahui signifikan tidaknya pengaruh dari amsing-masing variabel bebas terhadap variabel terikat (Sanusi, 2014:138)

- Secara Serentak (simultan)

Menunjukkan bahwa variasi variabel terikat dijelaskan sekian persen oleh variabel bebas secara bersama-sama adalah benar-benar nyata dan bukan terjadi secara kebetulan (Sanusi, 2014:137)

\section{IV.ANALISIS \& PEMBAHASAN}

\subsection{Statistik Deskriptif}

Analisis ini bertujuan untuk mengetahui tren nilai terendah (minimum), nilai tertinggi (maximum), nilai rata-rata (mean) dan standar deviasinya sehingga penulis dapat mendeskriptifkan hasil penelitian yang berupa angka-angka kedalam analisis. Berikut ini ditampilkan data statistik secara umum dari seluruh data yang digunakan :

Tabel 1. Statistik Deskriptif

\begin{tabular}{|l|r|r|r|r|r|}
\hline & $\mathrm{N}$ & Minimum & Maximum & \multicolumn{1}{c|}{ Mean } & Std. Deviation \\
\hline DER & 68 &, 0810 & 13,5432 & 1,772368 & 2,4713052 \\
NPM & 68 &, 0236 & 1,3628 &, 230790 &, 2262878 \\
SIZE & 68 & 26,7382 & 32,9217 & 29,533965 & 1,5989312 \\
LN_Y & 68 & 5,11 & 10,37 & 8,1784 & 1,62092 \\
Valid N (listwise) & 68 & & & & \\
\hline
\end{tabular}

Sumber : Data Olahan, 2019

Dari tabel tersebut, dapat dijelaskan bahwa rata-rata DER adalah 1,772368 dengan standar deviasi 2,4713052. Nilai maksimum adalah 13,5432 dan nilai terendah adalah 0,0810. Hal ini dapat di indikasikan bahwa data bervariatif dan menyebar di antara nilai maksimum dan nilai minimum. Rata-rata NPM adalah 0,230790 dengan standar deviasi 0,2262878. Nilai maksimum adalah 1,3628 dan nilai minimum 0,0236 . Hal ini dapat di indikasikan bahwa data bervariatif dan menyebar di antara nilai maksimum dan nilai minimum. Rata-rata Ukuran perusahaan adalah 29,533965 dengan standar deviasi 1,5989312. Nilai maksimum adalah 32,9217 dan nilai minimum 26,7382. Hal ini dapat di indikasikan bahwa data bervariatif dan menyebar di antara nilai maksimum dan nilai minimum Rata-rata Harga Saham adalah 8,1784 dengan standar deviasi 1,62092. Nilai maksimum adalah 10,37 dan nilai minimum 5,11. Hal 
ini dapat di indikasikan bahwa data bervariatif dan menyebar di antara nilai maksimum dan nilai minimum. Jumlah sampel adalah sebanyak 68 buah yang diperoleh dari 17 perusahaan dari tahun 2014 sampai tahun 2017.

\subsection{Hasil Uji Normalitas}

Untuk mengetahui apakah ada data yang memiliki normal atau tidak, dapat digunakan uji statistik Kolmogrov-Smirnov $(K-S)$. Hasil dari uji normalitas dengan menggunakan tes kolmogorov-smirnov $(K-S)$ adalah seperti yang terlihat pada Tabel berikut :

Tabel 2. Hasil Uji Normalitas

One-Sample Kolmogorov-Smirnov Test

\begin{tabular}{|ll|r|}
\hline & & $\begin{array}{c}\text { Unstandardized } \\
\text { Residual }\end{array}$ \\
\hline Normal Parameters ${ }^{\mathrm{a}, \mathrm{b}}$ & Mean & 68 \\
& Std. Deviation &, 0000000 \\
Most Extreme Differences & Absolute & 1,15164857 \\
& Positive &, 080 \\
& Negative &, 058 \\
Kolmogorov-Smirnov Z & &,- 080 \\
Asymp. Sig. (2-tailed) & &, 663 \\
\hline
\end{tabular}

a. Test distribution is Normal.

b. Calculated from data.

Sumber : Data Olahan, 2019

Berdasarkan Tabel 2 diatas diketahui bahwa semua variabel DER, NPM, Ukuran Perusahaan dan harga Saham berdistribusi normal karena nilai signifikansi $>0,05$.

\subsection{Hasil Uji Multikolinieritas}

Pengujian ini bermaksud untuk menguji apakah pada model regresi ditemukan adanya korelasi antar variabel bebas. Jika terjadi korelasi, maka dinamakan terdapat problem multikolinieritas. Hasil dari uji multikolinieritas dapat dilihat pada Tabel 3. berikut :

Tabel 3. Hasil Uji Multikolinieritas

Coefficients $^{\mathrm{a}}$

\begin{tabular}{|c|c|c|}
\hline \multirow[t]{2}{*}{ Model } & \multicolumn{2}{|c|}{ Collinearity Statistics } \\
\hline & Tolerance & VIF \\
\hline (Cons & & \\
\hline DER & ,962 & 1,040 \\
\hline NPM & ,981 & 1,079 \\
\hline SIZE & ,978 & 1,022 \\
\hline
\end{tabular}

Sumber : Data Olahan, 2019

Berdasarkan hasil pengujian di atas, dapat dilihat bahwa angka tolerance dari masing-masing variabel > 0,10 dan nilai VIF (Variance Inflation Factor) < 10, maka dapat disimpulkan tidak ada multikolinieritas antar variabel independent tersebut. 


\subsection{Hasil Uji Autokorelasi}

Hasil uji Autoregresi dapat dilihat pada tabel 4. berikut :

Tabel 4. Hasil Uji Autokorelasi

\begin{tabular}{|l|l|}
\hline Model & Durbin-Watson \\
\hline 1 & \\
\hline \multicolumn{2}{|c|}{ Sumber : Data Olahan, 2019 } \\
\hline
\end{tabular}

Untuk mengetahui terjadi atau tidaknya autokorelasi maka terlebih dahulu menetapkan nilai dl dan du. Berdasarkan tabel Durbin Watson (dw) pada sampel (n) 68 dari variabel independen sebanyak 3 maka dapat diketahui nilai $d_{L}$ sebesar 1,525 dan nilai $d_{U}$ sebesar 1,703 maka dapat disimpulkan bahwa nilai $\mathrm{dw}<\mathrm{d}_{\mathrm{L}}$ dan $\mathrm{dw}>\mathrm{d}_{\mathrm{U}}$. Maka koefesien korelasi tidak sama dengan nol,berarti tidak terjadi autokorelasi positif dan negatif pada model regresi penelitian disebabkan rentang data yang cukup dekat.

\subsection{Hasil Uji Heteroskadisitas}

Hasil dari uji hetroskadisitas dapat ditunjukan dalam tabel Spearman Rho berikut :

Tabel 5. Hasil Uji Spearman Rho

\begin{tabular}{|c|c|c|c|c|c|c|}
\hline \multicolumn{7}{|c|}{ Correlations } \\
\hline & & & DER & NPM & SIZE & $\begin{array}{c}\text { Unstandardi } \\
\text { zed } \\
\text { Residual }\end{array}$ \\
\hline \multirow{12}{*}{$\begin{array}{l}\text { Spear } \\
\text { man's } \\
\text { rho }\end{array}$} & \multirow[t]{3}{*}{ DER } & $\begin{array}{l}\text { Correlation } \\
\text { Coefficient }\end{array}$ & 1,000 & ,180 & ,149 &,- 147 \\
\hline & & Sig. (2-tailed) & & , 143 & 225 & 232 \\
\hline & & $\mathrm{N}$ & 68 & 68 & 68 & 68 \\
\hline & \multirow[t]{3}{*}{ NPM } & $\begin{array}{l}\text { Correlation } \\
\text { Coefficient }\end{array}$ & , 180 & 1,000 & ,251* & ,175 \\
\hline & & Sig. (2-tailed) & ,143 & & ,039 & , 153 \\
\hline & & $\mathrm{N}$ & 68 & 68 & 68 & 68 \\
\hline & \multirow[t]{3}{*}{ SIZE } & $\begin{array}{l}\text { Correlation } \\
\text { Coefficient }\end{array}$ & , 149 & ,251* & 1,000 & ,031 \\
\hline & & Sig. (2-tailed) & ,225 & ,039 & . & ,803 \\
\hline & & $\mathrm{N}$ & 68 & 68 & 68 & 68 \\
\hline & \multirow[t]{3}{*}{$\begin{array}{l}\text { Unstandardized } \\
\text { Residual }\end{array}$} & $\begin{array}{l}\text { Correlation } \\
\text { Coefficient }\end{array}$ &,- 147 & , 175 & ,031 & 1,000 \\
\hline & & Sig. (2-tailed) & ,232 & , 153 & ,803 & . \\
\hline & & $\mathrm{N}$ & 68 & 68 & 68 & 68 \\
\hline
\end{tabular}

*. Correlation is significant at the 0.05 level (2-tailed).

Sumber : Data Olahan, 2019 


\subsection{Model Analisis Regresi Regresi Berganda}

Berdasarkan hasil regresi berganda, maka diperoleh model penelitian sebagai berikut :

$$
\mathrm{Y}=\mathbf{- 9 , 4 4 7}+\text { 0,051DER +2,608NPM+0,573 Ukuran Perusahaan }
$$

1. Nilai a sebesar -9,447artinya jika variabel DER, NPM dan Ukuran perusahaan konstan (tetap) maka harga saham (Y) adalah sebesar -9,447.

2. Nilai $\beta_{1}$ sebesar 0,051 artinya setiap peningkatan DER 1 satuan maka akan meningkatkanharga saham sebesar 0,051 satuan.

3. Nilai $\beta_{2}$ sebesar 2,608 artinya setiap peningkatan NPM 1 satuan maka akan meningkatkan harga saham sebesar 2,608 satuan.

4. Nilai $\beta_{3}$ sebesar 0,573 artinya setiap peningkatan Ukuran perusahaan 1 satuan maka akan meningkatkan harga saham sebesar 0,573 satuan.

\subsection{Hasil Uji Koefesien Determinasi}

Nilai koefesien determinasi $\left(\mathrm{R}^{2}\right)$ dipergunakan untuk mengukur besarnya pengaruh variabel bebas dari DER, NPM dan ukuran perusahaan dengan harga saham pada perusahaan Infrastruktur, Utilitasdan transportasi yang terdaftar di Bursa Efek Indonesia.

\section{Tabel .6 Hasil Koefesien Determinasi}

\begin{tabular}{|c|r|r|r|r|}
\hline \multicolumn{5}{|c|}{ Model Summary $^{\mathrm{b}}$} \\
$\mathrm{R}$ & $\mathrm{R}$ Square & $\begin{array}{c}\text { Ajusted R } \\
\text { Square }\end{array}$ & $\begin{array}{c}\text { Std. Error of the } \\
\text { Estimate }\end{array}$ & Durbin-Watson \\
\hline, $679^{\mathrm{a}}$ &, 461 &, 436 & 6742,138 & 1,946 \\
\hline
\end{tabular}

Sumber : Data Olahan, 2019

Berdasarkan Tabel di atas diperoleh nilai koefesien determinasi sebesar 0,461 atau sebesar 46,1\% variabel DER, NPM dan Ukuran perusahaan yang dapat menjelaskan harga saham pada perusahaan infrastruktur, utilitasdan transportasi yang terdaftar di Bursa Efek Indonesia sebesar 46,1\%. Sedangkan sisanya sebesar 53,9\% dapat dijelaskan dari variabel bebas lainnya yang tidak diteliti dalam penelitian ini.

\subsection{Pengujian Hipotesis Hasil Uji Secara Parsial (Uji t)}

Tabel 7. Hasil Uji Parsial 


\begin{tabular}{|c|c|c|c|c|c|c|}
\hline \multicolumn{7}{|c|}{ Coefficients $^{a}$} \\
\hline \multirow{2}{*}{\multicolumn{2}{|c|}{ Model }} & \multicolumn{2}{|c|}{ Unstandardized Coefficients } & \multirow{2}{*}{$\begin{array}{c}\text { Standardized } \\
\text { Coefficients } \\
\text { Beta }\end{array}$} & \multirow[b]{2}{*}{$\mathrm{t}$} & \multirow[b]{2}{*}{ Sig. } \\
\hline & & B & Std. Error & & & \\
\hline \multirow[t]{4}{*}{1} & (Constant) & $-9,447$ & 2,679 & & $-3,526$ & ,001 \\
\hline & DER & ,051 & 059 & 077 & ,854 & ,396 \\
\hline & NPM & 2,608 & 642 & ,364 & 4,061 & ,000 \\
\hline & SIZE &, 573 & 091 &, 566 & 6,299 &, 000 \\
\hline
\end{tabular}

a. Dependent Variable: LN_Y

Sumber : Data Olahan, 2019

Berdasarkan hasil pengujian hipotesis pengaruh DER terhadap harga saham diperolehnilai thitung $(0,854)$ lebih kecil dari tabel $(1,9971)$ dengan signifikansi 0,396 (Sig.> 0,05) maka Ho diterima dan Ha ditolak. Artinya secara parsial DER tidak berpengaruh terhadap harga saham pada perusahaan Infrastruktur, utilitas and transportasi yang terdaftar di Bursa Efek Indonesia. Hasil penelitian ini tidak sejalan dengan penelitian terdahulu yaitu penelitian Putu Dina dan Suaryana dengan judul "Pengaruh EPS, DER, dan PBV terhadap Harga Saham" yang menjelaskan bahwa secara parsial DER berpengaruh dan signifikan terhadap harga saham.

Berdasarkan hasil pengujian hipotesis pengaruh NPM terhadap harga sahamdiperolehnilai thitung $(4,061)$ lebih besar dari -t tabel $(1,9971)$ dengan signifikansi 0,000 (Sig.< 0,05) maka Ho ditolak dan Ha diterima. Artinya secara parsial NPM berpengaruh positif dan signifikan terhadap hargasaham pada perusahaan Infrastruktur, utilitas and transportasi yang terdaftar di Bursa Efek Indonesia. Hasil penelitian ini sejalan dengan penelitian terdahulu yaitu penelitian Edhi Asmirantho dan Elif Yuliawati dengan judul "Pengaruh Dividend Per Share (DPS), Dividend Payout Ratio (DPR), Price to Book Value (PBV), Debt to Equity Ratio (DER), $\quad$ Net Profit Margin (NPM), dan Return On Asset (ROA) terhadap Harga Saham pada perusahaan Manufaktur sub sektor makanan dan minuman dalam kemasan yang terdaftar di BEI" yang menjelaskan bahwa secara parsial NPM berpengaruh positif dan signifikan terhadap harga saham.

Berdasarkan hasil pengujian hipotesis pengaruh firm size terhadap harga saham diperolehnilai $t_{\text {hitung }}(6,299)$ lebih besar dari - $t_{\text {tabel }}(1,9971)$ dengan signifikansi 0,000 (Sig.< 0,05) maka Ho ditolak dan Ha diterima. Artinya secara parsial Ukuran perusahaan berpengaruh positif dan signifikan terhadap hargasaham pada perusahaan Infrastruktur, utilitas and transportasi yang terdaftar di Bursa Efek Indonesia. Hasil penelitian ini sejalan dengan penelitian terdahulu yaitu penelitian Pujo Gunarso dengan judul "Laba Akuntansi, Leverage dan Ukuran Perusahaan terhadap Harga Saham di Bursa Efek Indonesia” yang menjelaskan bahwa secara parsial ukuran perusahaan berpengaruh positif dan signifikan terhadap harga saham.

\subsection{Hasil Uji Simultan (Uji F)}

Pengujian secara simultan bertujuan untuk mengetahui ada tidaknya pengaruh variabel bebas secara bersama-sama dengan variabel terikat. Hasil pengujian secara simultan dapat dilihat sebagai berikut : 
Tabel 8. Hasil Uji F

\begin{tabular}{|c|c|c|c|c|c|c|}
\hline \multicolumn{7}{|c|}{ ANOVA $^{b}$} \\
\hline \multicolumn{2}{|c|}{ Model } & Sum of Squares & df & Mean Square & $\mathrm{F}$ & Sig. \\
\hline 1 & Regression & 87,174 & 3 & 29,058 & 20,928 &, $000^{a}$ \\
\hline & Residual & 88,862 & 64 & 1,388 & & \\
\hline & Total & & 67 & & & \\
\hline
\end{tabular}

a. Predictors: (Constant), SIZE, NPM, DER

b. Dependent Variable: LN_Y

Sumber : Data Olahan, 2019

Berdasarkan hasil pengujian hipotesis pengaruh efesiensi operasional DER, NPM dan Ukuran perusahaan terhadap Harga Saham diperoleh nilai $F_{\text {hitung }}(20,928)$ lebih besar dari Ftabel $(2,76)$ dengan signifikansi 0,000 (Sig.< 0,05) maka Ha diterima. Artinya secara simultan DER, NPM dan Ukuran perusahaan berpengaruh signifikan terhadap Harga Saham pada perusahaan Infrastruktur, utilitas dan transportasi yang terdaftar di Bursa Efek Indonesia.

\section{KESIMPULAN}

\subsection{Kesimpulan}

1. Hasil pengujian secara parsial membuktikan bahwa variabel DER tidak berpengaruh signifikan terhadap harga saham. Hal ini dapat dilihat dari hasil pengujian hipotesis yang nilai signifikansinya lebih besar dari 0,05 yang berarti hipotesis ditolak.

2. Hasil pengujian secara parsial membuktikan bahwa variabel NPM berpengaruh positif dan signifikan terhadap harga saham. Hal ini dapat dilihat dari hasil pengujian hipotesis yang nilai signifikansinya lebih kecil dari 0,05 yang berarti hipotesis diterima.

3. Hasil pengujian secara parsial membuktikan bahwa variabel Ukuran perusahaan berpengaruh positif dan signifikan terhadap harga saham. Hal ini dapat dilihat dari hasil pengujian hipotesis yang nilai signifikansinya lebih kecil dari 0,05 yang berarti hipotesis diterima.

4. Hasil penelitian ini juga membuktikan bahwa DER, NPM dan Ukuran perusahaan secara bersama-sama berpengaruh signifikan terhadap harga saham karena mempunyai tingkat signifikansi lebih kecil dari 0,05 (5\%), yang berarti hipotesis diterima.

\section{DAFTAR PUSTAKA}

Darmadji, dkk. (2011). Pasar Modal Indonesia, Edisi 3, Salemba Empat, Jakarta.

Edhi Asmirantho dan Elif Yuliawati (2015). Pengaruh Dividend Per Share (DPS), Dividend Payout Ratio (DPR), Price to Book Value (PBV), Debt to Equity Ratio (DER), Net Profit Margin (NPM), dan Return On Asset (ROA) terhadap Harga Saham pada perusahaan Manufaktur sub sektor makanan dan minuman dalam kemasan yang terdaftar di BEI. JIAFE (Jurnal Ilmiah Akuntansi Fakultas Ekonomi), E-ISSN 25024159, Volume 1, No. 2 Tahun 2015, Hal. 95-117

Fahmi, Irham (2012). Manajemen Investasi: Teori dan Soal Jawab. Edisi 2. Jakarta: Salemba Empat

Frendy Sondakh, Prengkuan Tommy, Marjam Mangantar (2015). Pengaruh CR, DER, ROA dan ROE terhadap harga saham pada perusahaan Indeks LQ 45 di Bursa Efek 
Indonesia periode 2010-2014.Jurnal EMBA, Vol.3 No.2. Diakses Juni 2015, Hal. 749-756

Ghozali (2013). Aplikasi Analisis Multivariate Dengan Program Ibm Spss 21. Ed. 7, Semarang: Alfabeta

Hery. (2015). Analisis Laporan Keuangan. Ed. 1. Cetakan Ketiga. Jakarta: Bumi Aksara Kasmir (2012). Analisis Laporan Keuangan. Cetakan Kelima. Jakarta: RajawaliPers Kodrat, David Sukardi dan Indonanjaya, Kurniawan (2010). Manajemen Investasi: Pendekatan Teknikal Analisis Saham. Yogyakarta: Gaha Ilmu

Priyatno, Duwi (2017). Panduan Praktis Olah Data menggunakan SPSS. Yogyakarta:GAVA MEDIA

Pujo Gunarso (2014). Laba Akuntansi, Leverage dan Ukuran Perusahaan terhadap Harga Saham di Bursa Efek Indonesia" Jurnal Keuangan dan Perbankan, Vol-18, No.1 Januari 2014, hal 63-71

Putu Dina Arystia Dewi dan Suaryana (2013). Pengaruh EPS, DER, dan PBV terhadap Harga Saham. E-jurnal Akutansi Universitas Udayana 4-1, ISSN: 2302-8556, hal 215-229

Ramdhani (2017). Ekonomi Islam Akuntansi dan Perbankan Syariah. Jakarta: CAPS

Riyanto, Bambang (2009). Dasar-dasar Pembelanjaan Perusahaan. BFFE-Yogyakarta Riyanto, Bambang (2013). Pendekatan Rasio Keuangan. Jakarta: CAPS.

Rosdiana Widianti Watung, Ventje Ilat (2016). Pengaruh ROA, NPM, dan EPS terhadap harga saham pada perusahaaan Perbankan di bursa efek indonesia periode 2011-2015. Jurnal EMBA Vol.4 No.2. Diakses Juni 2016, Hal. 518-529

Ruttanti Indah Mentari (2013). Dampak ROE, NPM,CSR, dan Ukuran Perusahaan terhadap harga saham perusahaan yang tercantum dalam LQ45 di BEI Periode 2010-2012. Jurnal Akuntansi, UDINUS. Vol .1

Sanusi, Anwar (2014). Meteodologi Penelitian Bisnis. Cetakan Kedua. Jakarta: Salemba Empat

Sartono (2010). Manejemen Keuangan: Teori Dan Aplikasi. Ed. 4, Yogyakarta: BPFE

Sudana, I Made (2015). Manajemen Keuangan Perusahaan Teknik dan Praktik. Surabaya: Erlangga

Sugiyono (2012). Metode Penelitian Kuantitatif, Kualitatif dan R\&F. Cet. 10 Bandung: Alfabeta

Sujarweni. (2014). Metodologi Penelitian. Cetakan Pertama. Yogyakarta: PUSTAKABARUPRESS

Umam dan Sutanto. (2017). Manajemen Investasi. Bandung: Pustaka Setia www.idx.co.id 